\title{
Binding of estrogen receptor $\alpha / \beta$ heterodimers to chromatin in MCF-7 cells
}

\author{
Zoi Papoutsi, Chunyan Zhao, Milica Putnik, Jan-Åke Gustafsson \\ and Karin Dahlman-Wright
}

Department of Biosciences and Nutrition, Karolinska Institutet, NOVUM, SE 14157 Huddinge, Sweden

(Correspondence should be addressed to Z Papoutsi; Email: zoi.papoutsi@ki.se)

\begin{abstract}
Estrogen receptors (ERs), ER $\alpha$ and $E R \beta$, belong to a group of transcription factors that, upon ligand binding, regulate gene expression by binding to specific DNA regions in chromatin as dimers. In this article, we applied the sequential chromatin immunoprecipitation assay (Re-ChIP) to study the simultaneous presence of $E R \alpha$ and $E R \beta$ on various DNA-binding regions in intact chromatin. ER $\alpha / \beta$ heterodimers were isolated by precipitation with anti-ER $\beta$ antibody followed by anti-ER $\alpha$ antibody from a stable MCF-7-derived cell line that expresses endogenous ER $\alpha$ and an inducible version of ER $\beta$. The $\mathrm{Re}-\mathrm{ChIP}$ method was first validated based on the detection of $E R \alpha / \beta$ heterodimers bound to a promoter region of the $p S 2$ gene known to bind both ER $\alpha$ and $E R \beta$. We next examined 12 ER-binding sites using Re-ChIP assays for ER $\alpha / \beta$ heterodimer recruitment. Our results confirmed the recruitment of $E R \alpha / \beta$ heterodimers to all these regions. This study represents the first demonstration of binding of $E R \alpha / \beta$ heterodimers to various DNA-binding regions in intact chromatin.
\end{abstract}

Journal of Molecular Endocrinology (2009) 43, 65-72

\section{Introduction}

Estrogen receptors (ERs), ER $\alpha$ and ER $\beta$, mediators of the biological actions of estrogens, belong to the nuclear receptor protein family. In the classical model of estrogen action, upon ligand binding, the receptor dimerizes, and binds to DNA, followed by recruitment of co-regulatory proteins and transcriptional regulation of target genes. $\mathrm{ER} \alpha$ and $\mathrm{ER} \beta$ are highly homologous, displaying 96 and 58\% homology in their DNA- and ligand-binding domains (LBD) respectively. The region that is responsible for receptor dimerization lies within the LBD (Dahlman-Wright et al. 2006). Although ER $\alpha$ and $\operatorname{ER} \beta$ are widely expressed throughout the body, they exhibit distinct expression patterns in a variety of tissues. $\mathrm{ER} \alpha$ is expressed primarily in the uterus, kidney, and liver, whereas ER $\beta$ is highly expressed in the prostate, lung, bladder, and central nervous system (Matthews et al. 2006).

The fact that there are two ERs suggests that heterodimerization $(\alpha / \beta)$ could play a role in estrogen signaling. The formation of $\mathrm{ER} \alpha / \beta$ heterodimers has been demonstrated using techniques such as glutathione-S-transferase (GST) pull-down assays (Pace et al. 1997, Pettersson et al. 1997, Ogawa et al. 1998) and gel shift assays (Cowley et al. 1997, Tremblay et al. 1999). The chromatin immunoprecipitation (ChIP) assay is a powerful tool to study protein:DNA interactions in their native chromatin context (Collas \& Dahl 2008). Several recent studies using ChIP assays have explored the binding of ER $\alpha$ and $E R \beta$ to DNA in intact chromatin in MCF-7 cells (Carroll et al. 2006, Liu et al. 2008). However, the association of $E R \alpha / \beta$ heterodimers to DNA was not investigated in these studies. Using sequential Chip with two antibodies (Re-ChIP), the simultaneous binding of two proteins to the same DNAbinding region can be demonstrated in the context of intact chromatin (Kouskouti \& Talianidis 2005).

In this article, we describe our studies of the binding of $\mathrm{ER} \alpha / \beta$ heterodimers to various DNA-binding regions in intact chromatin, applying the Re-ChIP method to a stable MCF7-derived cell line that expresses endogenous $\mathrm{ER} \alpha$ and an inducible version of $\mathrm{ER} \beta$.

\section{Materials and methods}

\section{Generation of tetracycline-inducible stable cell lines}

MCF-7 Tet-Off cells were purchased from Clontech and maintained in DMEM/F-12 supplemented with $10 \%$ (v/v) fetal bovine serum (FBS) and $100 \mu \mathrm{g} / \mathrm{ml} \mathrm{G418}$ (Invitrogen). The cells were transfected with either the parental plasmid (pBI-EGFP) to generate a mock cell line or a plasmid (pBI-EGFP-ER $\beta$ ) expressing a flag-tagged human ER $\beta$ using the Lipofectamine 2000 reagent (Invitrogen). Cells were selected in the presence of $5 \mu \mathrm{g} / \mathrm{ml}$ blasticidin for 10 days. ER $\beta$ protein levels were determined by western blot analysis. In order to confirm the functionality of the ER $\beta$ protein, we examined its effect on cell proliferation. 
We evaluated the cell cycle distribution by fluorescence activated cell sorter analysis (FACS) in both MCF-7 mock and MCF-7 ER $\beta$ expressing cells after 72-h stimulation with $\mathrm{E}_{2}$. The FACS analysis revealed a decrease in the percentage of cells in the $\mathrm{S}$ phase in MCF-7 ER $\beta$ cells, 12\% compared with 18\% in MCF-7 mock cells (data not shown). This finding is in line with previously published data, where overexpression of ER $\beta$ inhibited the proliferation of breast cancer cells (Chang et al. 2006, Williams et al. 2008).

\section{RNA purification and quantification of mRNA levels}

To assay ER $\alpha$ and ER $\beta$ mRNA levels, MCF-7 ER $\beta$ and MCF-7 mock cells were seeded in six-well plates and grown in the absence of tetracycline (-tet, $+\mathrm{ER} \beta$ ) for 4 days. To assay mRNA levels of ER target genes, MCF-7 ER $\beta$ and MCF-7 mock cells were seeded in six-well plates and grown in 5\% FBS dextran-coated charcoal-treated DMEM phenol red free media in the absence of tetracycline (-tet, $+\mathrm{ER} \beta$ ) for 2 days, followed by incubation with $10 \mathrm{nM} \mathrm{E}_{2}$ for $24 \mathrm{~h}$. Total RNA were purified using the RNeasy Mini Kit (Qiagen). Two microgram total RNA from each well was reverse transcribed into cDNA using TaqMan Reverse Transcription Reagents (Applied Biosystems) with random hexamer primers. Real-time (RT) PCR assays were conducted using the Applied Biosystems 7500 fast RT PCR system with SYBR green master mix RT-PCR reagent (Applied Biosystems, Stockholm, Sweden). All RT-PCRs were performed in duplicate. Acidic ribosomal phosphoprotein PO (36B4) was used as internal control gene (Akamine et al. 2007). The sequences of the primers are listed in Table 1.

\section{Western blot analysis of ER $\alpha$ and ER $\beta$ protein levels}

MCF-7 ER $\beta$ and MCF-7 mock cells were seeded in $150 \mathrm{~mm}$ dishes and grown in the absence of tetracycline $(-$ tet, $+\mathrm{ER} \beta)$ for 4 days. Total cell extracts were prepared as previously described (Zhao et al. 2007). Aliquots corresponding to $40 \mu \mathrm{g}$ cell extract and 1-10 ng human recombinant ER $\alpha$ and ER $\beta$ (Invitrogen) were separated by SDS/PAGE. For quantification of $\operatorname{ER} \beta$ and $E R \alpha$ protein levels, we used the anti-ER $\beta$ rabbit polyclonal antibody LBD, developed in our laboratory (Omoto et al. 2001) and the anti-ER $\alpha$ rabbit polyclonal antibody HC-20 (Santa Cruz, Stockholm, Sweden). Protein bands were quantified with densitometry using Scion Image Software, Maryland, USA.

\section{Chromatin immunoprecipitation/ re-immunoprecipitation}

MCF-7 ER $\beta$ and MCF-7 mock cells were seeded in $150 \mathrm{~mm}$ dishes and grown in the absence of tetracycline $(-$ tet, $+\mathrm{ER} \beta)$ for 4 days. Cells were treated with $10 \mathrm{nM}$ $\mathrm{E}_{2}$ for $45 \mathrm{~min}$ and ChIP was performed as previously described (Matthews et al. 2006, Liu et al. 2008). The anti-ER $\beta$ rabbit polyclonal antibody LBD (Omoto et al. 2001) was used to perform ChIP for ER $\beta$ and the rabbit polyclonal anti-ER $\alpha$ antibody HC-20 (Santa Cruz) was used for ER $\alpha$ ChIP. The rabbit polyclonal anti-RNA polymerase II antibody H-224 (Santa Cruz) was used for RNA polymerase II ChIP. Normal rabbit IgG was used for the determination of non-specific binding. For Re-ChIP, ChIP was performed with the anti-ER $\beta$ LBD antibody or the anti-ER $\alpha$ antibody HC-20. Beads from the first cycle of ChIP were incubated with an equal volume of $10 \mathrm{nM}$ dithiothreitol at $37^{\circ} \mathrm{C}$ for $30 \mathrm{~min}$, centrifuged at $16000 \mathrm{~g}$ for $1 \mathrm{~min}$ to elute DNA-bound proteins. The elution was repeated twice. The final elute was diluted 1:15 in lysis buffer containing a protease inhibitor cocktail (Roche) and re-immunoprecipitated with the anti-ER $\alpha$ HC-20 antibody, the antiPol II H-224 antibody, or normal rabbit IgG. The final pellet was processed for western blotting (ChIP protein) or, after reverse cross-linking, for PCR or RT PCR (ChIP DNA).

Table 1 Primer pairs employed to quantify mRNA levels of estrogen receptors $(E R \alpha, E R \beta)$, the internal control gene, acidic ribosomal phosphoprotein PO (36B4), as well as of some selected genes

Forward

$\begin{array}{ll}E R \alpha & \text { GAA TCT GCC AAG GAG ACT CGC } \\ E R \beta & \text { TGT CTG CAG CGA TTA CGC A } \\ 36 B 4 & \text { GTG TTC GAC AAT GGC AGC AT } \\ \text { pS2 } & \text { CATCGACGTCCCTCCAGAAGAG } \\ \text { NBPF1 } & \text { CACAGCACCTTGTCCAAAAGC } \\ \text { NBPF4 } & \text { TGTTGCCAGGGATTACTCCAA } \\ \text { NOTCH2 } & \text { GGGAACAGCAAGACATGCAA } \\ \text { BCL9 } & \text { CCAAACGATGACTCTGACATTAAAGA } \\ \text { PRUNE } & \text { CAGAGATCTTGGACAGGCAAACT } \\ \text { ADORA1 } & \text { TTCCACACCTGCCTCATGGT }\end{array}$

Reverse

ACT GGT TGG TGG CTG GAC AC GCG CCG GTT TTT ATC GAT T GAC ACC CTC CAG GAA GCG A CTCTGGGACTAATCACCGTGCTG TGAACATCTTCATCGTCATCGTT AGATCACTTTGCTTTTCGAGGAA TGGTCACAGTGGTTGTCTTTGAA TGGTGTGTGCTGGGAATCC TGTTGACACAGTCCAGGATGATG GCGGTCCACAGCAATTGC 


\section{Re-ChIP followed by western blotting, PCR or RT PCR}

Total ChIP protein was eluted from beads and separated by SDS/PAGE followed by detection with the anti-flag M5 monoclonal antibody (Sigma). Equal amounts of PCR product after amplification with $\mathrm{pS} 2$ primers (Table 2) were analyzed by gel electrophoresis and visualized by ethidium bromide staining. Immunoprecipitated DNA was amplified by RT PCR using Platinum SYBR green quantitative PCR supermix uracil DNA glycosylase (Invitrogen). The primer sequences for the 14 genes that were investigated are given in Table 2.

\section{Results}

\section{The MCF-7 ER $\beta$ cell line expresses similar levels of $E R \alpha$ and ER $\beta$}

A stable cell line, MCF-7 ER $\beta$, that expresses an inducible version of ER $\beta$ fused to a flag tag, was used in all experiments. The MCF-7 mock cell line, a clone of MCF-7 stably transfected with the empty vector, was used as a negative control for ER $\beta$ expression. The cell lines express endogenous ER $\alpha$. Initially, we measured the mRNA levels of both $E R \alpha$ and $E R \beta$ at conditions similar to those of the ChIP and Re-ChIP experiments. As shown in Fig. 1A, the MCF-7 mock cell line and the MCF-7 ER $\beta$ cell line express equal amounts of ER $\alpha$ mRNA levels. In the MCF-7 ER $\beta$ cell line, ER $\beta$ mRNA levels were similar to those of $\mathrm{ER} \alpha$, while the $E R \beta \mathrm{mRNA}$ levels were undetectable in the MCF-7 mock cell line. Protein levels of $\mathrm{ER} \alpha$ and $\mathrm{ER} \beta$ were quantified, under the same conditions, by western blot analysis using purified ER $\alpha$ and ER $\beta$ proteins as standards. As shown in Fig. 1B, high levels of ER $\beta$ protein were observed in the MCF-7 ER $\beta$ cell line, whereas no expression of ER $\beta$ was detected in the MCF-7 mock cell line. In Fig. 1C, the amounts of expressed ER $\alpha$ and ER $\beta$ proteins are shown as derived from comparison with those of the corresponding purified proteins of known concentration. This analysis revealed that the protein ratio of $\mathrm{ER} \alpha: \mathrm{ER} \beta$ is $07: 1$ in the MCF-7 ER $\beta$ cell line under the conditions used in our ChIP and Re-ChIP experiments.

\section{Binding of $E R \alpha / \beta$ heterodimers to DNA in intact chromatin}

To demonstrate binding of $\mathrm{ER} \alpha / \beta$ heterodimers to intact chromatin, we performed Re-ChIP experiments. $\mathrm{ER} \alpha / \beta$ heterodimers were isolated by precipitation with the anti-ER $\beta$ antibody followed by the anti-ER $\alpha$ antibody. DNA-bound $E R \alpha / \beta$ was confirmed by western blot analysis showing that ER $\beta$ can be detected in protein-DNA complexes after sequential precipitation with anti-ER $\beta$ and anti-ER $\alpha$ antibodies. The interaction of $\mathrm{ER} \alpha / \beta$ heterodimers with specific DNA-binding regions was further assessed by conventional PCR targeting a region of the $\mathrm{pS} 2$ promoter known to bind $\mathrm{ER} \alpha$ and ER $\beta$ (Fig. 2A). Additionally, binding to the pS2 promoter region, after sequential immunoprecipitation with ER $\beta$ and $\mathrm{ER} \alpha$ antibodies, was confirmed using RT PCR. As shown in Fig. 2B, a significant recruitment of $\mathrm{ER} \alpha$ to the $\mathrm{pS} 2$ promoter was observed in the MCF-7 mock cell line, while $\mathrm{ER} \alpha$, and $\mathrm{ER} \beta$, as well as $\mathrm{ER} \alpha / \beta$ heterodimers, were recruited to the pS2 promoter in the MCF-7 ER $\beta$ cell line.

Our group has recently identified genome-wide ER $\alpha$ and ER $\beta$-binding regions in the MCF-7 ER $\beta$ cell line by the ChIP-on-chip assay (unpublished data). Based on this information, 12 regions (each labeled by the closest gene in Fig. 3) that were identified as binding regions for both $\mathrm{ER} \alpha$ and $\operatorname{ER} \beta$ with similar signal intensity in the ChIP-on-chip analysis (ratio of ChIP sample to input sample) were selected for further studies of the

Table 2 Primer pairs for amplification of chromatin immunoprecipitation assay (ChIP) and Re-ChIP enriched regions

Forward

$18 S$
pS2
NBPF1
NBPF4
VANGL1
NOTCH2
NOTCH2NL
BCL9
NBPF15
PRUNE
PBX1
NR5A2
ADORA1
CAPN2

GCTTAATTTGACTCAACACGGGA

CCT CCC GCC AGG GTA AAT AC AGC GGC ATC CCC AGT GT GGC TGC AGA GGT GGG TAT GA GGC TTG GCT TGT GCT ACG A CCA TTC TTG CTC TTG CCT TAG AG CAG CAG GTC AGA TTC CAT CGA TTG ACA GAA GCC CTG GAG ATG CTT GTT TTA GCT CAT CTG TCC ATC A GAG AGC AAA AAG CCA AGG TTA CA TTC CTG CCG GCT TTG TGG AAG CAA AGA GAT GAT GGA TGT AAC TC GAT GGA TGG GAA CAC ATT GGT CTG GCA TCT GCC TAC AGC AA
Reverse

AGCTATCAATCTGTCAATCCTGTC
CCG GCC ATC TCT CAC TAT GAA
AGG GTG CCT GGA GCT TAA GC
GCC CCA TTG GCA GAT CAC T
AGT TAG GGT GGC AGC AAC CTT
GCT TGT GGC CAT GTT TTG C
TGA GAG CCT GTT TTC TTG AGC AT
GCC TGC CAG GTT TCA GGA A
GGG TGA AAA GTC AGC CGT TTA T
ACA GCC TCG GCA AAT ATC TTC T
GCC TGC CGT GAC CTC TTC TA
CCT TTT TCC TCC CCA GTT GTG
TGG TGG CGG AGC ACA AA
GTG TCA TTG TGC CCC AAC AG
AGG GTG CCT GGA GCT TAA GC GCC CCA TTG GCA GAT CAC T AGT TAG GGT GGC AGC AAC CTT GCT TGT GGC CAT GTT TTG C TGA GAG CCT GTT TTC TTG AGC AT GCC TGC CAG GTT TCA GGA A GGG TGA AAA GTC AGC CGT TTA T GCC TGC CGT GAC CTC TTC TA TGG TGG CGG AGC ACA AA GTG TCA TTG TGC CCC AAC AG 


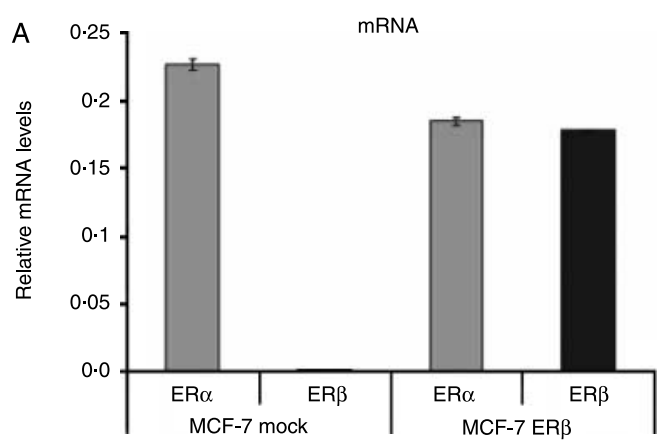

B
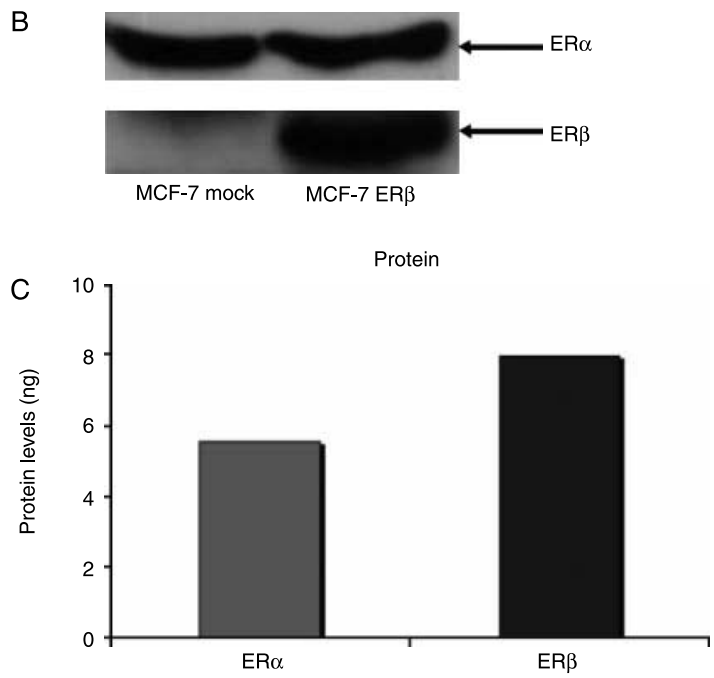

Figure 1 (A) $E R \alpha$ and $E R \beta$ mRNA levels in MCF-7 mock and MCF-7 ER $\beta$ cell lines. Cells were grown in the absence of tetracycline for 4 days. Data are presented as relative mRNA levels compared with acidic ribosomal phosphoprotein PO (36B4). Results represent the mean \pm s.D. values of two independent experiments conducted in six replicates. (B) ER $\alpha$ and ER $\beta$ protein levels in total cell extracts from MCF-7 ER $\beta$ cell lines determined by western blot analysis. Cell extracts were separated by SDS/PAGE. Anti-ER $\beta$ and anti-ER $\alpha$ antibodies were used for detection as indicated. (C) Quantification of ER $\alpha$ and ER $\beta$ protein levels in MCF-7 cells were based on standard curves (1-10 ng protein) made with pure recombinant ER $\alpha$ and ER $\beta$ proteins. Purified and expressed protein bands were quantified by densitometry using Scion Image Software.

binding of $\mathrm{ER} \alpha / \beta$ heterodimers to DNA. Regions from the $\mathrm{pS} 2$ promoter and the $18 S$ gene, which serve as ER-bound positive control and ER-bound negative control respectively were also included in the experiments.

The binding of $\operatorname{ER} \alpha$ and $\operatorname{ER} \beta$ to these DNA-binding regions was confirmed using ChIP followed by RT PCR (Fig. 3). All the binding sites exhibited similar fold enrichment for both ERs. There was no recruitment of any ER to a region of the $18 S$ gene in the MCF-7 ER $\beta$ cell line. In the MCF-7 mock cell line, with no expression of $E R \beta$, there was no detectable recruitment of ER $\beta$ to any of the binding sites tested, while the recruitment of ER $\alpha$ was similar to that in the MCF-7 ER $\beta$ cell line (data not shown).

To study the binding of $\mathrm{ER} \alpha / \beta$ heterodimers to these regions in the context of intact chromatin, we performed Re-ChIP experiments. Re-ChIP was performed with the anti-ER $\beta$ antibody followed by the anti$\mathrm{ER} \alpha$ antibody and precipitated DNA was analyzed using RT PCR. In the MCF-7 ER $\beta$ cell line, all analyzed binding regions from the $p S 2$ (trefoil factor 1 ), neuroblastoma breakpoint family, member 4 (NBPF4), NOTCH Drosophila homolog 2 (NOTCH2), NOTCH Drosophila homolog 2 N-terminal like (NOTCH2NL), NBPF15, PRUNE (Drosophila h-prune homolog), B-cell chronic lymphoblastic leukemia/lymphoma 9 (BCL9), pre-B-cell leukemia homeobox 1 (PBX1), nuclear receptor subfamily 5 , group $\mathrm{A}$, member 2 (NR5A2), adenosine A1 receptor (ADORA1), calpain 2 (CAPN2), $N B P F 1$, and Van Gogh-like 1 (VANGL1) genes exhibited significant fold enrichment of $\mathrm{ER} \alpha / \mathrm{ER} \beta$ heterodimers, whereas there was no enrichment to the analyzed region of $18 \mathrm{~S}$ (Fig. 4).

A
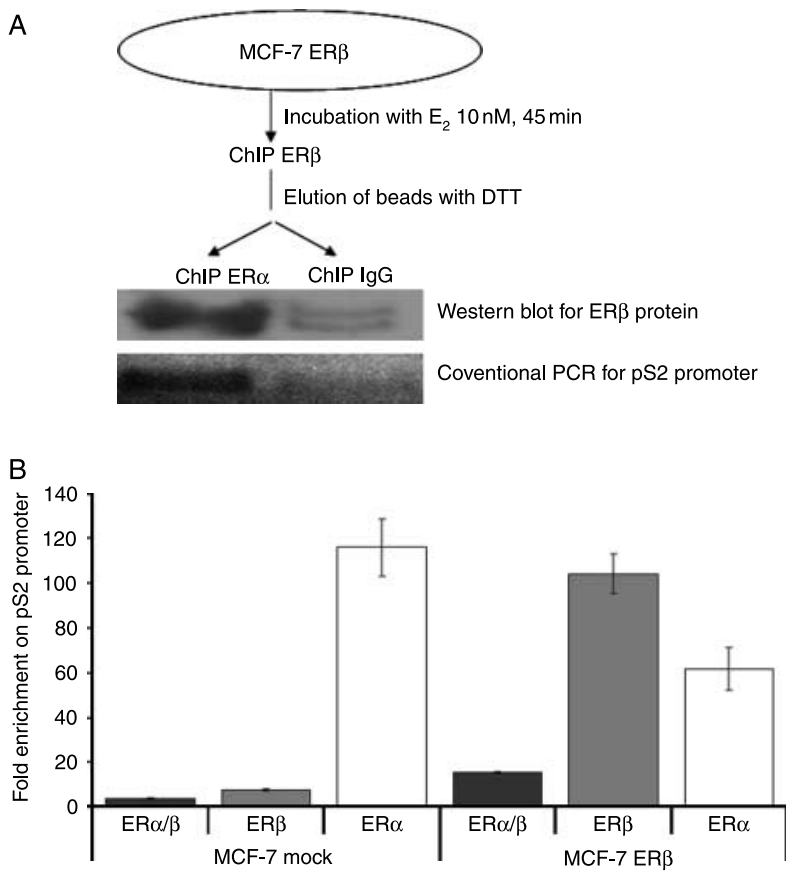

Figure 2 (A) Experimental design for the Re-ChIP assay. Confirmation of $E R \alpha / \beta$ heterodimers was based on the flag tag detection of the ER $\beta$ protein by western blotting and on the amplification of a fragment from the $\mathrm{pS} 2$ promoter by conventional PCR. (B) ER $\alpha, E R \beta$, and $E R \alpha / E R \beta$ recruitment to the pS2 promoter. MCF-7 mock and MCF-7 ER $\beta$ cells were treated and processed for ChIP and Re-ChIP assays as described in Materials and methods. Binding of $E R \alpha, E R \beta$, and $E R \alpha / E R \beta$ in immunoprecipitated fractions to a fragment from the pS2 promoter was confirmed by real-time PCR. Data are presented as fold enrichment of $\mathrm{ER} \alpha, \mathrm{ER} \beta$, and $\mathrm{ER} \alpha / \beta$ binding compared with IgG (means \pm S.D., $n=2$ ). 


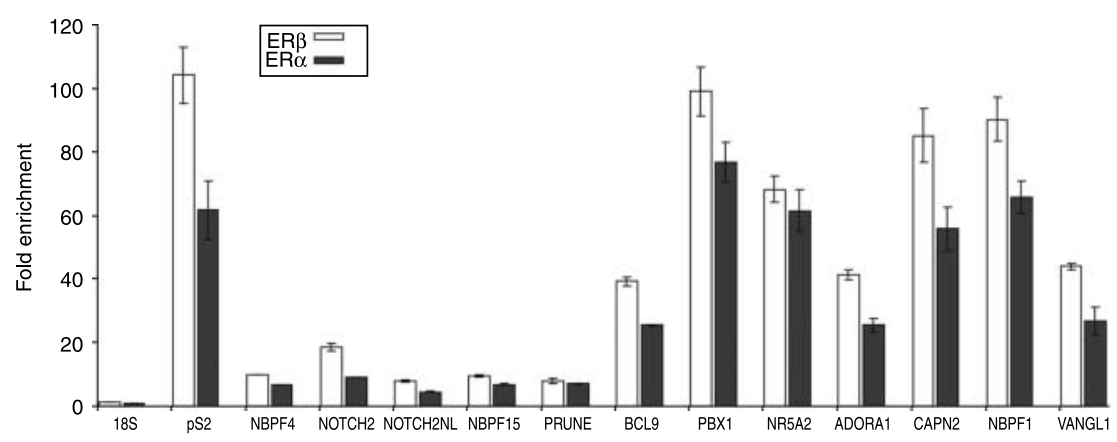

Figure $3 \mathrm{ER} \alpha$ and ER $\beta$ recruitment to DNA-binding regions. MCF-7 ER $\beta$ cells were treated and processed for ChIP assays as described in Materials and methods. Real-time PCR was performed to confirm the binding of $E R \alpha$ and $E R \beta$ to various DNA-binding regions in immunoprecipitated fractions as indicated. Data are presented as fold enrichment of $E R \alpha$ or $\mathrm{ER} \beta$ binding compared with IgG (means \pm s.D., $n=2$ ). A fragment from the $\mathrm{pS} 2$ promoter was used as positive control while a fragment from the $18 \mathrm{~s}$ was used as negative control for ER binding.

\section{Recruitment of RNA polymerase II to ER $\alpha / \beta$-bound DNA regions}

To investigate the effect of ER $\beta$ on transcriptional regulation and in particular on the recruitment of RNA polymerase II, we performed ChIP experiments using an anti-PolII antibody. As shown in Fig. 5A, PolII is recruited to the $\mathrm{pS} 2$ promoter in both the MCF-7 mock and the MCF-7 ER $\beta$ cell lines. However, the PolII recruitment is significantly decreased by ER $\beta$ expression in the MCF-7 ER $\beta$ cell line (Fig. 5A). Re-ChIP assays (ER $\beta /$ PolII, ER $\alpha /$ PolII and ER $\beta / E R \alpha$ ) were used to assay co-recruitment of ERs and RNA polymerase II to the pS2 promoter. As shown in Fig. 5B, a significant co-recruitment of $\mathrm{ER} \alpha$ and PolII to the pS2 promoter was observed in the MCF-7 mock cell line, while, as expected, there was no co-recruitment of ER $\beta$ and PolII or ER $\alpha$ and ER $\beta$ in this cell line. In the MCF-7 ER $\beta$ cell line, significant recruitment to the pS2 promoter was observed for all three Re-ChIP assays, suggesting that PolII co-exists with ER $\alpha$ and ER $\beta$ on this binding site.

\section{Estrogen treatment affects expression of genes close to ER $\alpha / \beta$-bound DNA regions}

To assay whether the presence of ER $\beta$ affects the expression of ER $\alpha$-mediated transcription, we compared the mRNA levels of seven selected genes in the MCF-7 ER $\beta$ cell line versus the MCF-7 mock cell line in response to $\mathrm{E}_{2}$ treatment and increased expression of all tested genes, following $\mathrm{E}_{2}$ treatment, was observed in the MCF-7 mock cell line (Fig. 6). Interestingly, in the presence of ER $\beta$, the expression of $p S 2$, ADORA1, $N B P F 1$, and NBPF4 was decreased, the expression of $P R U N E$ and NOTCH2 not changed while the expression of $B C L 9$ was increased.

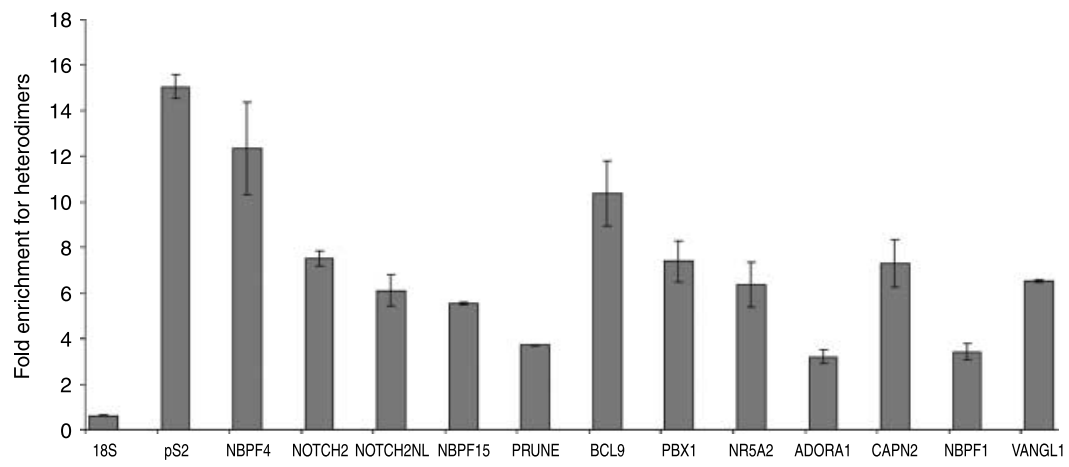

Figure $4 \mathrm{ER} \alpha / \beta$ heterodimer recruitment to DNA-binding regions. MCF-7 ER $\beta$ cells were treated and processed for Re-ChIP assay as described in Materials and methods. Realtime PCR on DNA from $E R \alpha / \beta$ immunoprecipitated fractions was performed on regions from various genes as indicated. Data are presented as fold enrichment of $E R \alpha / \beta$ binding compared with IgG (means \pm s.D., $n=2$ ). A fragment from the $\mathrm{pS} 2$ promoter was used as positive control while a fragment from the $18 \mathrm{~s}$ was used as negative control for ER binding. 

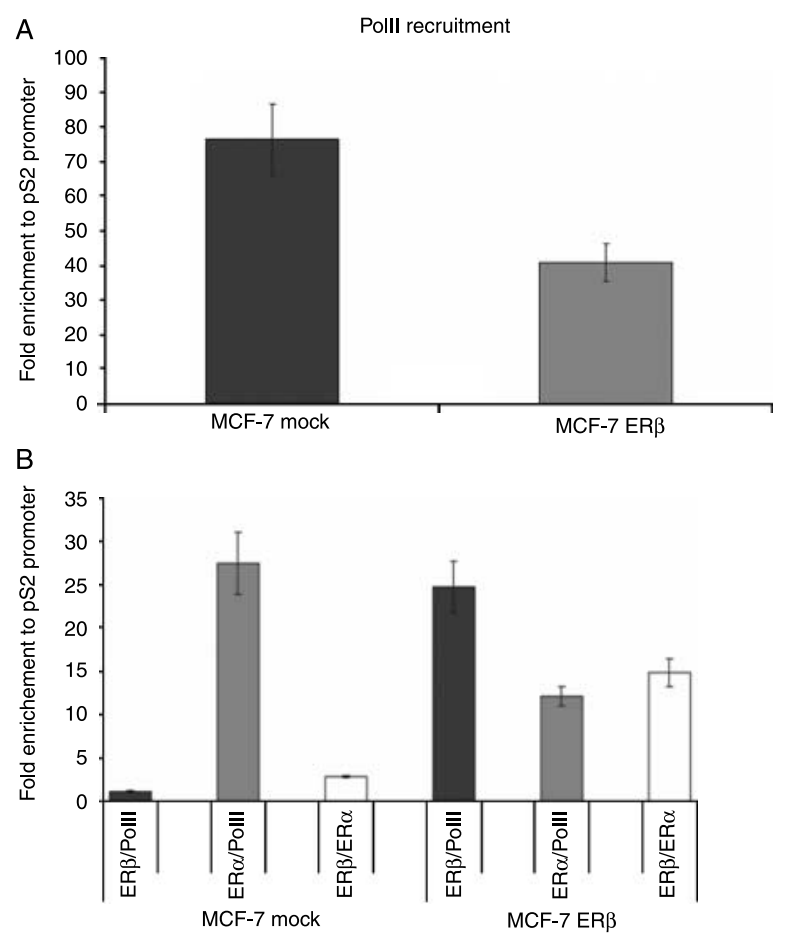

Figure 5 (A) Polll recruitment to pS2 promoter. (B) ER $\beta /$ Polll, $E R \alpha / P o l l I$, and $E R \beta / E R \alpha$ recruitment to $p S 2$ promoter. MCF-7 mock and MCF-7 ER $\beta$ cells were treated and processed for ChIP or Re-ChIP assays as described in Materials and methods. Binding of Polll alone or ER $\beta / P o l l l, E R \alpha / P o l l I$, and ER $\beta / E R \alpha$ in immunoprecipitated fractions to a fragment from the pS2 promoter was confirmed by real-time PCR. Data are presented as fold enrichment of Polll alone or ER $\beta / P o l l I, E R \alpha / P o l l l$, and ER $\beta / E R \alpha$ compared with $\operatorname{lgG}$ (means \pm s.D., $n=2$ ).

\section{Discussion}

In this study, we report the identification of $E R \alpha / \beta$ heterodimer-binding DNA regions in MCF-7 ER $\beta$ cells that express an inducible version of ER $\beta$ and endogenous ER $\alpha$, using a Re-ChIP assay. As a negative control, we used a mock MCF-7 cell line. Although the

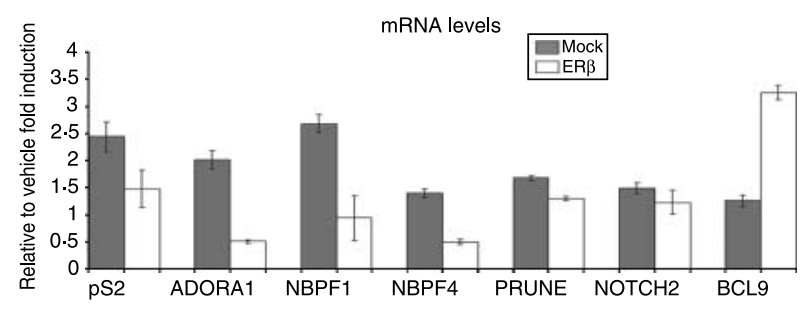

Figure 6 mRNA levels of selected genes in MCF-7 mock and MCF-7 ER $\beta$ cell lines. Cells were treated and processed for RNA extraction and analysis of mRNA levels as described in Materials and methods. Data are presented of $E_{2}$ treated cells relative to vehicle treated cells after normalization to acidic ribosomal phosphoprotein PO (36B4). Results represent the mean \pm S.D. values of two independent experiments conducted in six replicates. formation of $\mathrm{ER} \alpha / \beta$ heterodimers has been previously demonstrated using GST-pull down and gel-shift assays (Pace et al. 1997, Pettersson et al. 1997), the exact role of $\mathrm{ER} \alpha / \beta$ heterodimers in estrogen signaling remains largely unknown. However, it is assumed that in cell types, where the two receptor subtypes are co-expressed, the formation of $\mathrm{ER} \alpha / \beta$ heterodimers plays an important role in $\mathrm{E}_{2}$ signaling (Matthews et al. 2006).

Recent studies have explored the ER $\alpha$ - and ER $\beta$ binding sites for whole genomes or for specific chromosomes (Carroll et al. 2006, Liu et al. 2008); following up on these studies, we studied $\mathrm{ER} \alpha / \beta$ heterodimers in a cell system where both $\mathrm{ER} \alpha$ and ER $\beta$ are expressed. It has been observed previously that the extent of formation of $\mathrm{ER} \alpha / \beta$ heterodimers in a system, with both ERs are present, depends upon the relative amount of contributing receptors ( $\mathrm{Li}$ et al. 2004). Under conditions of co expression of ERs at similar levels, we applied a Re-ChIP assay, followed by RT PCR, to characterize in a quantitative manner the recruitment of $\mathrm{ER} \alpha / \beta$ heterodimers to various DNAbinding regions in intact chromatin. We detected, by western blotting the ER $\beta$ protein only in the ER $\beta$-ER $\alpha$ and not in the ER $\beta-\operatorname{IgG}$ immunoprecipitated samples after Re-ChIP assay (Fig. 2A). We confirmed the presence of $\mathrm{ER} \alpha / \beta$ heterodimers on the $\mathrm{pS} 2$ promoter, a well-characterized promoter to which both $\mathrm{ER} \alpha$ and ER $\beta$ bound in the MCF-7 ER $\beta$ cell line (Zhao et al. 2007). As shown in Fig. 2, amplification of the pS2 promoter was only detected in ER $\beta-\mathrm{ER} \alpha$ immunoprecipitated fractions from the MCF-7 ER $\beta$ cell line Previously, Monroe et al. (2005) showed binding of $\mathrm{ER} \alpha / \beta$ heterodimers to chromatin in a modified osteoblast cell line by amplifying ER-binding region of two genes, RBBP1 and DHCR7.

In order to study the simultaneous presence of $\mathrm{ER} \alpha / \beta$ heterodimers on various binding sites in intact chromatin, we queried ER-binding sites recently mapped by the ChIP-on-chip assay (data not shown) and randomly selected 12 DNA regions, which showed similar signal intensity (ratio of ChIP sample to input sample) in the ChIP-on-chip assay for ER $\alpha$ and ER $\beta$. Notably, eight binding sites are located within genes (NBPF1, NBPF4, VANGL1, NOTCH2, NOTCH2NL, BCL9, $N B P F 15$, and $P B X 1$ ), and the residual four are located in the promoter regions (NR5A2, ADORA1, CAPN2, and PRUNE).

To confirm the recruitment of both ER $\alpha$ and ER $\beta$ to the regions identified by the ChIP on chip experiment, we performed ChIP assays using ER $\alpha$ or ER $\beta$ antibodies. All the binding sites tested exhibited significant recruitment of $\operatorname{ER} \alpha$ and $\operatorname{ER} \beta$ and the level of recruitment was similar for both receptors. Next, we examined the binding of $E R \alpha / \beta$ heterodimers to the selected DNA regions using a Re-ChIP assay. In the MCF-7 ER $\beta$ cell line, all the investigated DNA-binding regions 
showed significant recruitment of heterodimers. However, it is notable that different binding sites exhibit different fold enrichment of $\mathrm{ER} \alpha / \beta$ heterodimers. This could be attributed to variations in affinity of heterodimers to various ER-binding sites depending upon the sequence of the binding regions. In a preliminary analysis, using the CONSITE program (Sandelin et al. 2004) and setting TF-score cut-off at $85 \%$, we found that all of the selected binding sites contained half-ERE motif, $70 \%$ contained AP1-motif (pS2, NOTCH2, NOTCH2NL, PRUNE, BCL9, NR5A2, ADORA1, NBPF1, and VANGL1), but only $23 \%$ contained fullERE (pS2, NR5A2, and ADORA1). However, the detailed dissection of the mechanism of heterodimers' recruitment needs a larger number of such identified regions and a systematic binding motifs enrichment analysis with strict background control. Furthermore, our data showed that the ratio of enrichment in the $\mathrm{ER} \alpha / \beta \mathrm{Re}-\mathrm{ChIP}$ assay versus the enrichment in the $\mathrm{ER} \alpha$ and ER $\beta$ ChIP assays varied. For example, for genes such as NBPF4, NOTCH2, NBPF15, and PRUNE, this ratio is high, suggesting that heterodimer recruitment may play a more significant role in the transcriptional regulation of these genes. Our results also showed that overall there is less recruitment of heterodimers compared with $\mathrm{ER} \alpha$ or ER $\beta$ alone. This may be due to the recovery being less after two rounds of ChIP (Re-Chip assay) compared with the single ChIP assay. Additionally, previous kinetic studies have revealed that heterodimers exhibit low binding affinity (Jisa \& Jungbauer 2003).

Previous work has shown that the presence of ER $\beta$ can affect ER $\alpha$ 's transcriptional activity (Chang et al. 2006). To verify this in our cell system, we evaluated the mRNA levels of some selected genes after $\mathrm{E}_{2}$ treatment. Our data showed that mRNA levels of genes that are implicated in cell proliferation, like pS2, and Adora1 are down-regulated, when ER $\beta$ is expressed (Ribieras et al. 1998, Mirza et al. 2005). The decrease of $p S 2 \mathrm{mRNA}$ levels in the MCF-7 ER $\beta$ cells is in accordance with the decrease of PollI recruitment to the pS2 promoter in the same cell line as compared with MCF-7 mock cells. The mRNA levels of NBPF1 and NBPF4, whose function is not fully explored, are also decreased in the presence of ER $\beta$ (Vandepoele et al. 2005). mRNA levels of BCL9, which is participating in the wnt signaling of cell proliferation and development, were up-regulated in the MCF-7 ER $\beta$ cell line compared with the MCF-7 mock cell line (Willert \& Jones 2006). Finally, the mRNA levels of NOTCH2 and PRUNE were unaffected by the presence of ER $\beta$. These genes are both implicated in the aggressiveness of breast neoplasm (Marino \& Zollo 2007, Wang et al. 2008). Considering that all selected genes exhibit significant $\mathrm{ER} \alpha / \beta$ heterodimer recruitment, our data suggest that ER $\beta$ may have an activating or inhibitory influence on ER $\alpha$ through heterodimerization. Furthermore, using a
Re-ChIP assay and various combinations of ER $\alpha, \mathrm{ER} \beta$, and PolII antibodies, we showed that PolII co-occupied the same DNA-binding regions as ER $\alpha$ and ER $\beta$, consistent with a role of $\mathrm{ER} \alpha / \beta$ heterodimers in transcriptional regulation.

In this study, we report the recruitment of $\mathrm{ER} \alpha / \beta$ heterodimers to various ER-binding DNA regions in an intact cell system, following $\mathrm{E}_{2}$ treatment. Further experimental data are needed to elucidate the detailed mechanism of formation of ER $\alpha / \beta$ heterodimers, their function, and the influence of ligands.

\section{Declaration of interest}

We declare that there is no conflict of interest that could be perceived as prejudicing the impartiality of the research reported.

\section{Funding}

This work was supported by grants from the Swedish Cancer Fund (grant number 08-0573) and from KaroBio AB. Jan-Åke Gustafsson is a shareholder and consultant of KaroBio AB.

\section{References}

Akamine R, Yamamoto T, Watanabe M, Yamazaki N, Kataoka M, Ishikawa M, Ooie T, Baba Y \& Shinohara Y 2007 Usefulness of the $5^{\prime}$ region of the cDNA encoding acidic ribosomal phosphoprotein $\mathrm{P} 0$ conserved among rats, mice, and humans as a standard probe for gene expression analysis in different tissues and animal species. Journal of Biochemical and Biophysical Methods 70 481-486.

Carroll JS, Meyer CA, Song J, Li W, Geistlinger TR, Eeckhoute J, Brodsky AS, Keeton EK, Fertuck KC, Hall GF et al. 2006 Genomewide analysis of estrogen receptor binding sites. Nature Genetics $\mathbf{3 8}$ 1289-1297.

Chang EC, Frasor J, Komm B \& Katzenellenbogen BS 2006 Impact of estrogen receptor beta on gene networks regulated by estrogen receptor alpha in breast cancer cells. Endocrinology 147 4831-4842.

Collas P \& Dahl JA 2008 Chop it, ChIP it, check it: the current status of chromatin immunoprecipitation. Frontiers in Bioscience 13 929-943.

Cowley SM, Hoare S, Mosselman S \& Parker MG 1997 Estrogen receptors alpha and beta form heterodimers on DNA. Journal of Biological Chemistry 272 19858-19862.

Dahlman-Wright K, Cavailles V, Fuqua SA, Jordan VC, Katzenellenbogen JA, Korach KS, Maggi A, Muramatsu M, Parker MG \& Gustafsson JA 2006 International Union of Pharmacology. LXIV. Estrogen receptors. Pharmacological Reviews 58 773-781.

Jisa E \& Jungbauer A 2003 Kinetic analysis of estrogen receptor homoand heterodimerization in vitro. Journal of Steroid Biochemistry and Molecular Biology 84 141-148.

Kouskouti A \& Talianidis I 2005 Histone modifications defining active genes persist after transcriptional and mitotic inactivation. $E M B O$ Journal 24 347-357.

Li X, Huang J, Yi P, Bambara RA, Hilf R \& Muyan M 2004 Single-chain estrogen receptors (ERs) reveal that the ERalpha/beta heterodimer emulates functions of the ERalpha dimer in genomic estrogen signaling pathways. Molecular and Cellular Biology 24 7681-7694.

Liu Y, Gao H, Marstrand TT, Strom A, Valen E, Sandelin A, Gustafsson JA \& Dahlman-Wright K 2008 The genome landscape of ERalphaand ERbeta-binding DNA regions. PNAS 105 2604-2609.

Marino N \& Zollo M 2007 Understanding h-prune biology in the fight against cancer. Clinical and Experimental Metastasis 24 637-645. 
Matthews J, Wihlen B, Tujague M, Wan J, Strom A \& Gustafsson JA 2006 Estrogen receptor (ER) beta modulates ERalpha-mediated transcriptional activation by altering the recruitment of c-Fos and c-Jun to estrogen-responsive promoters. Molecular Endocrinology 20 534-543.

Mirza A, Basso A, Black S, Malkowski M, Kwee L, Pachter JA, Lachowicz JE, Wang Y \& Liu S 2005 RNA interference targeting of A1 receptoroverexpressing breast carcinoma cells leads to diminished rates of cell proliferation and induction of apoptosis. Cancer Biology and Therapy 4 1355-1360.

Monroe DG, Secreto FJ, Subramaniam M, Getz BJ, Khosla S \& Spelsberg TC 2005 Estrogen receptor alpha and beta heterodimers exert unique effects on estrogen- and tamoxifen-dependent gene expression in human U2OS osteosarcoma cells. Molecular Endocrinology 19 1555-1568.

Ogawa S, Inoue S, Watanabe T, Hiroi H, Orimo A, Hosoi T, Ouchi Y \& Muramatsu M 1998 The complete primary structure of human estrogen receptor beta (hER beta) and its heterodimerization with ER alpha in vivo and in vitro. Biochemical and Biophysical Research Communications 243 122-126.

Omoto Y, Kobayashi Y, Nishida K, Tsuchiya E, Eguchi H, Nakagawa K, Ishikawa Y, Yamori T, Iwase H, Fujii Y et al. 2001 Expression, function, and clinical implications of the estrogen receptor beta in human lung cancers. Biochemical and Biophysical Research Communications 285 340-347.

Pace P, Taylor J, Suntharalingam S, Coombes RC \& Ali S 1997 Human estrogen receptor beta binds DNA in a manner similar to and dimerizes with estrogen receptor alpha. Journal of Biological Chemistry 272 25832-25838.

Pettersson K, Grandien K, Kuiper GG \& Gustafsson JA 1997 Mouse estrogen receptor beta forms estrogen response element-binding heterodimers with estrogen receptor alpha. Molecular Endocrinology 11 1486-1496.
Ribieras S, Tomasetto C \& Rio MC 1998 The pS2/TFF1 trefoil factor, from basic research to clinical applications. Biochimica et Biophysica Acta 1378 F61-F77.

Sandelin A, Wasserman WW \& Lenhard B 2004 ConSite: web-based prediction of regulatory elements using cross-species comparison. Nucleic Acids Research 32 W249-W252.

Tremblay GB, Tremblay A, Labrie F \& Giguere V 1999 Dominant activity of activation function 1 (AF-1) and differential stoichiometric requirements for AF-1 and -2 in the estrogen receptor alpha-beta heterodimeric complex. Molecular and Cellular Biology 19 1919-1927.

Vandepoele K, Van Roy N, Staes K, Speleman F \& van Roy F 2005 A novel gene family NBPF: intricate structure generated by gene duplications during primate evolution. Molecular Biology and Evolution 22 2265-2274.

Wang Z, Li Y, Banerjee S \& Sarkar FH 2008 Exploitation of the Notch signaling pathway as a novel target for cancer therapy. Anticancer Research 28 3621-3630.

Willert K \& Jones KA $2006 \mathrm{Wnt}$ signaling: is the party in the nucleus? Genes and Development 20 1394-1404.

Williams C, Edvardsson K, Lewandowski SA, Strom A \& Gustafsson JA 2008 A genome-wide study of the repressive effects of estrogen receptor beta on estrogen receptor alpha signaling in breast cancer cells. Oncogene 27 1019-1032.

Zhao C, Matthews J, Tujague M, Wan J, Strom A, Toresson G, Lam EW, Cheng G, Gustafsson JA \& Dahlman-Wright K 2007 Estrogen receptor beta2 negatively regulates the transactivation of estrogen receptor alpha in human breast cancer cells. Cancer Research 67 $3955-3962$.

Received in final form 21 March 2009

Accepted 16 April 2009

Made available online as an Accepted Preprint 17 April 2009 